\title{
ANALISIS EFISIENSI DAN FAKTOR-FAKTOR PRODUKSI KOMODITAS SEKTOR BASIS KABUPATEN PATI (Studi Kasus Budidaya Ikan Bandeng Kabupaten Pati, Jawa Tengah) Efficiency and Production Factors Analysis of Base Sector Commodity in the Pati Regency (Case Study: Milkfish Farming in Pati Regency, Central Java)
}

\author{
*Triana Dwi Wahyuni, Sasongko dan Sri Muljaningsih \\ Fakultas Ekonomi dan Bisnis, Universitas Brawijaya \\ JI. M.T. Haryono No.165, Ketawanggede, Kec. Lowokwaru, Kota Malang, Jawa Timur 65300, Indonesia \\ Diterima tanggal: 24 Januari 2019 Diterima setelah perbaikan: 10 Mei 2019 \\ Disetujui terbit: 30 Juni 2019
}

\begin{abstract}
ABSTRAK
Penelitian ini bertujuan untuk mengukur tingkat efisiensi teknik pada pembudidaya ikan bandeng dan faktor-faktor yang mempengaruhi produksi ikan bandeng sebagai komoditas sektor basis di Kabupaten Pati. Metode penelitian yang digunakan adalah dengan analisis DEA (Data Envelopment Analysis) dengan asumsi output oriented dan pendekatan Variable Return to Scale (VRS) untuk mengukur tingkat efisiensi teknik pembudidaya bandeng. Selanjutnya dengan analisis regresi linear berganda, untuk mengetahui faktor-faktor yang mempengaruhi produksi bandeng di Kabupaten Pati. Hasil penelitian menunjukkan bahwa tingkat efisiensi teknis pembudidaya bandeng di Kabupaten Pati masih sangat rendah, rata-rata efisiensi teknis adalah 7,41. Adapun sebanyak $55 \%$ atau sebanyak 44 pembudidaya dari 80 sampel pembudidaya masih berada di bawah rata-rata. Hasil analisis regresi diperoleh bahwa penggunaan benih, luas lahan, dan jarak lokasi tambak dengan laut mempunyai pengaruh yang sangat signifikan; Sedangkan penggunaan tenaga kerja tidak berpengaruh secara signifikan terhadap produksi bandeng.
\end{abstract}

Kata Kunci: ekonomi basis; efisiensi teknik; DEA; fungsi produksi cobb-douglass; pembudidaya bandeng

\begin{abstract}
This study aims to measure the level of technical efficiency in milkfish farmers and factors influencing milkfish production as a base sector commodity in Pati Regency. The research applied DEA (Data Envelopment Analysis) with output oriented assumption and Variable Return to Scale (VRS) approaches to measure the efficiency level of milkfish farmers. It is then analysed by Ordinary Least Squares (OLS) to determine factors influencing milkfish production in Pati Regency. Results showed that the level of technical efficiency of milkfish farmers in Pati Regency was in low level with average number of 7.41 . There are $55 \%$ of 80 farmers are below average. Furthermore, this research described the efficiency level of milkfish farmers in low, medium and large scale. OLS analysis found that the use of seeds, land area, and distance between ponds and sea have significant effect on milkfish production instead of the use of labour.
\end{abstract}

Keywords: economic base; technical efficiency; DEA; cobb-douglass function; milkfish farmer

\section{PENDAHULUAN}

Berlakunya Undang-Undang No 32 tahun 2004 Tentang Pemerintah Daerah dan UU No 34 Tahun 2004 Tentang Perimbangan Keuangan Pemerintah Pusat dan Daerah menjadi titik tolak berlakunya sistem desentralisasi di Indonesia atau yang lebih dikenal dengan otonomi daerah. Dengan prinsip otonomi yang luas, nyata dan bertanggung jawab, daerah dalam hal ini kabupaten dan kota diberikan keleluasaandalam mengatur rumah tangga pemerintahannya sendiri termasuk dalam menentukan model pembangunan daerah dan penggalian sumber-sumber dana pembangunan yang disesuaikan dengan kondisi dan potensi daerah masing-masing. Otonomi daerah telah memberikan wewenang yang luas kepada daerah kabupaten/kota dalam dalam mengatur berbagai mekanisme kekuasaan dan mengelola rumah tangganya sendiri, mulai tahap perencanaan, 
pelaksanaan, evaluasi, sampai dengan mekanisme pembiayaan pembangunan daerah (Ananda, 2017). Terkait dengan hal tersebut, maka daerah akan bekerja keras untuk menggali dan mengoptimalkan sumber-sumber potensi yang dapat memacu pertumbuhan daerah guna mewujudkan tujuan otonomi daerah (Sabarno, 2008). Dengan kata lain, daerah telah diberikan kewenangan dan peluang yang luas bagi pengembangan potensi ekonomi, sosial, politik dan budaya. Daerah dituntut untuk melakukan penajaman orientasi pembangunan yang berbasis pada potensi daerah. Daerah didorong untuk lebih mampu mengambil peran dan prakarsa baik dalam perencanaan pembangunan, mengeksplorasi dan mengeksploitasi sumber daya secara optimal yang bertujuan untuk mensejahterakan masyarakat (Kuncoro, 2014). Dalam hal penggalian potensi suatu daerah maka diperlukan pendekatan ekonomi basis dan non basis. Teori basis ekonomi menyatakan bahwa besarnya permintaan terhadap barang dan jasa yang dihasilkan oleh daerah tersebut oleh daerah lain menjadi salah satu penentu pertumbuhan ekonomi (Arsyad, 1999). Sejalan dengan hal tersebut, Bendavid-Val (1991) menyatakan bahwa sektor basis ditentukan dengan besarnya ekspor barang dan jasa daerah ke daerah lain. Dari kegiatan ekspor tersebut akan memunculkan pendapatan bagi daerah penyedia barang dan jasa. Dari pendapatan tersebut akan menghidupkan sektor non basis.

Pertumbuhan ekonomi suatu daerah ditentukan oleh sektor basis yang dimiliki oleh daerah tersebut. Semakin banyak sektor basis yang dimiliki oleh suatu wilayah, maka pertumbuhan ekonomi daerah akan ikut meningkat (Tarigan, 2007). Sektor ekonomi basis akan menghadirkan efek pengganda (multiplier effect) lokal / regional akan memberikan dampak perubahan ekonomi pada seluruh perekonomian kota atau daerah. Efek pengganda digunakan untuk memperkirakan dampak perubahan dalam basis ekonomi pada pekerjaan di masa depan dan populasi kota dan wilayah (Alexander, 1954; Hoyd, 1954).Sehingga komoditas sektor basis yang unggul, kuat, berproduksi tinggi, efisien, dan berdaya saing tinggi, perlu dikembangkan oleh daerah dengan didukung oleh kebijakan pemerintah daerah yang tepat sasaran sehingga pertumbuhan ekonomi daerah akan meningkat, dan tujuan peningkatan kesejahteraan masyarakat juga akan tercapai.

Komoditas sektor basis yang efisien akan menentukan daya saing suatu daerah. World
Economic Forum (2014) memandang bahwa efisiensi pasar barang dan efisiensi pasar tenaga kerja, menjadi salah satu faktor pendorong pembentuk daya saing. (Institute for Management Development, 2014) menambahkan faktor efisiensi lembaga pemerintahan dan dunia usaha juga turut menentukan posisi daya saing suatu wilayah. Hallam dan Machado, (2014); Zhu et al. (2008) memandang efisiensi teknik suatu komoditas menjadi titik ukur daya saing komoditas tersebut.

Kabupaten Pati, merupakan salah satu wilayah di Provinsi Jawa Tengah yang memiliki luas wilayah di sepanjang jalur pantai utara, sehingga sangat cocok untuk budidaya tambak ikan bandeng. Pada tahun 2011 Kabupaten Pati, ditetapkan sebagai wilayah minapolitan budidaya ikan bandeng melalui Keputusan Menteri Kelautan dan Perikanan RI, Nomor KEP.39/MEN/2011 Tentang Perubahan Atas Keputusan Menteri Kelautan dan Perikanan Nomor KEP.32/MEN/2010 tentang Penetapan Kawasan Minapolitan. Hal ini juga ditunjang dengan produksi perikanan Kabupaten Pati pada tahun 2015 didominasi oleh perikanan tambak yang mencapai $30.007,84$ ton sekitar $45 \%$ dari total produksi perikanan Kabupaten Pati, disusul dengan perikanan laut yang mencapai $22.582,80$ ton atau $30 \%$, perikanan kolam $14.152,62$ ton atau $25 \%$, dan produksi ikan waduk 100,3 ton atau $0,33 \%$, ikan keramba 23,8 ton atau $0,04 \%$ dan ikan sawah yang hanya 15,28 ton atau $0,02 \%$. Komoditas budidaya tambak memang menjadi primadona Kabupaten Pati, pada khususnya adalah produksi Bandeng yang nilai produksi pada tahun 2015 mencapai 4,41 T Rupiah. Berdasarkan perhitungan Location Quotient (LQ) perikanan budidaya tambak di Kabupaten Pati memiliki nilai 1,8 dan berdasarkan rumah tangga perikanan budidaya tambak memiliki nilai $L Q$ 6,2 . Hal ini berarti, budidaya perikanan tambak di Kabupaten pati merupakan sektor ekonomi basis di Kabupaten Pati.

Potensi budidaya tambak di Kabupaten Pati, terbagi atas tiga komoditas, yakni bandeng, udang windu dan udang vaname. Berdasarkan data BPS Kabupaten Pati, pada tahun 2017, komoditas bandeng mencapai Rp377.849.850.000 komoditas udang windu mencapai Rp47.298.560.000 dan udang vaname mencapai Rp47.778.399.000. Besarnya potensi ikan bandeng tersebut, masih belum bisa menembus pasar internasional. Hal ini dikarenakan sebagian besar dilakukan oleh pembudidaya skala kecil dan hanya untuk pasar domestik. Pada umumnya 
pembudidaya skala kecil memiliki tantangan permodalan, sewa lahan yang tinggi, harga jual sangat tergantung pada permintaan pasar, bahkan pembudidaya rela menjual kepada siapa saja yang berminat membeli hasil panennya (Abbam, 2009; Achaw, 2010).

Tantangan lain yang dihadapi pembudidaya ikan bandeng di Kabupaten Pati adalah semakin menurunnya tingkat produksi ikan bandeng. Hal ini diduga karena pembudidaya bandeng sangat bergantung pada alam dan tingkat efisiensi yang masih rendah. Peningkatan produksi pembudidaya ikan bandeng dapat dilakukan dengan peningkatan efisiensi dalam penggunaan faktor-faktor inputnya. Peningkatan efisiensi dapat dilakukan dengan memperbaiki kemampuan manajerial pembudidaya, penyuluhan secara intensif, dan memperbaiki faktor-faktor yang menyebabkan inefisiensi pembudidaya.

\section{METODOLOGI}

Penelitian efisiensi produksi ikan bandeng sebagai sektor basis Kabupaten Pati merupakan penelitian yang membutuhkan pengolahan data yaitu perbandingan antara input dan output. Input dalam hal ini adalah jumlah benih, luas lahan, tenaga kerja dan jarak antara tambak dengan laut. Metode penelitian kuantitatif dipilih dikarenakan lebih mudah menginterpretasi dan menganalisa data, khususnya untuk mengetahui hubungan antara variabel input dan output dalam menjelaskan efisiensi komoditas sektor basis di Kabupaten Pati.

\section{Lokasi dan Waktu Penelitian}

Pengambilan data primer dilakukan pada bulan Juni-Juli 2018 di Kecamatan Juwana, Kabupaten Pati Provinsi Jawa Tengah dengan menggunakan kuesioner penelitian. Pemilihan lokasi didasarkan pada penetapan Kabupaten Pati sebagai wilayah minapolitan perikanan tambak. Kabupaten Pati berdasarkan data BPS, pada tahun 2016 menghasilkan ikan bandeng dengan total nilai produksi sebesar Rp377.8495.850.000 dan Kecamatan Juwana merupakan sentra produksi ikan bandeng di Kabupaten menghasilkan nilai produksi ikan bandeng sebesar Rp118.516.068.000 atau sebesar $31 \%$ dari total nilai produksi ikan bandeng Kabupaten Pati. Sehingga pemilihan lokasi penelitian ini dapat mewakili penelitian produksi ikan bandeng di Kabupaten Pati. Adapun pemilihan Kecamatan Juwana sebagai basis produksi bandeng di Kabupaten Pati, dikarenakan produksi ikan bandeng di Kecamatan Juwana melimpah sehingga dikirim ke luar (diekspor) Kabupaten Pati.

\section{Jenis dan Metode Pengambilan Data}

Pengambilan sampel penelitian dilakukan secara multistage purposive sampling. Metode pengambilan sampel secara multistage purposive sampling merupakan sistem pengambilan sampling dengan melakukan beberapa tingkat tahapan, dilanjutkan dengan pertimbangan khusus sehingga layak dijadikan sampel (Morissan, 2015). Pengambilan sampel secara purposive dengan asumsi populasi menyebar normal, maka jumlah sampel seluruhnya adalah 80 responden. Pengambilan sampel dengan teknik ini dilakukan karena pembudidaya tambak ikan bandeng dianggap relatif sama (homogen). Pengambilan jumlah responden pada penelitian ini adalah 80 responden. Hal ini didasarkan bahwa penelitian ini menggunakan 5 variabel (multivariat) dan pengambilan sampel untuk multivariat (termasuk dalam regresi berganda) minimal adalah 10x lebih besar dari jumlah variabel penelitian (Gay \& Diehl, 1992; Kothari, 2004) sehingga pengambilan 80 responden sudah memenuhi syarat pengambilan sampel. Adapun tahapan pengambilan sampel adalah sebagai berikut; dari tingkat Kabupaten Pati, dipilih Kecamatan Juwana karena memiliki wilayah tambak terluas di Kabupen Pati. Disamping itu Kecamatan Juwana merupakan sentra penghasil ikan bandeng di Kabupaten Pati. Selanjutnya, dari Kecamatan Juwana dipilih 5 desa dengan luas wilayah tambak terluas yaitu Desa Langgen Harjo, Desa Geneng Mulyo, Desa Agung Mulyo, Desa Bakaran Wetan dan Desa Bakaran Kulon. Dari kelima desa tersebut pengambilan sampel diambil secara acak. Penulis kemudian menggolongkan pembudidaya ikan bandeng dalam tiga skala yaitu pembudidaya dengan luas lahan di bawah $5 \mathrm{Ha}(<5 \mathrm{Ha})$ digolongkan dalam pembudidaya skala kecil, pembudidaya dengan luas lahan antara 5 Ha sampai dengan $10 \mathrm{Ha}$ ( $5 \mathrm{Ha} \leq \mathrm{x}<10 \mathrm{Ha}$ ) tergolong pembudidaya skala sedang dan pembudidaya dengan luas lahan di atas 10 ha digolongkan dalam pembudidaya skala besar.

\section{Metode Analisis}

\section{Analisis DEA (Data Envelopment Analysis)}

Pengukuran efisiensi produksi ikan bandeng sebagai komoditas sektor basis di Kabupaten 
Pati menggunakan program Data Envelopment Analysis (DEA). Data Envelopment Analysis (DEA) merupakan metode yang digunakan untuk mengevaluasi efisiensi operasi relatif dari berbagai unit kerja yang melaksanakanaktifitas yang sama dengan menggunakan input yang sama untuk menghasilkan output yang sama. DEA mengukur efisiensi relatif dari beberapa unit kerja yang terwujud dalam sebuah Decision Making Units (DMUs) (Rifa'i, 2013)

Dalam DEA, sebuah unit kegiatan ekonomi dikatakan efisien secara teknis apabila rasio perbandingan output produksi dan input yang digunakan sama dengan satu $(T E=1)$, artinya unit kegiatan ekonomi tersebut sudah tidak melakukan pemborosan input-input produksi atau mampu memanfaatkan potensi kemampuan produksi yang dimiliki secara optimal untuk menghasilkan output produksi yang tinggi.

Penerapan metode DEA diasumsikan dapat mengatasi keterbatasan yang dimilki oleh regresi berganda atau analisis rasio parsial. Analisis regresi dapat menunjukan elastisitas penggunaan input terhadap output yang dihasilkan dalam suatu sektor ekonomi. Sektor ekonomi dapat dinilai efisien apabila nilai output yang dihasilkan secara riil lebih tinggi dari nilai output yang dihasilkan dalam estimasi.

DEA menawarkan tiga orientasi dalam perhitungan efisiensi relatifnya yaitu (1) Model orientasi input (input-oriented model) yaitu model dimana setiap DMU diharapkan memproduksi sejumlah output tertentu dengan sejumlah input terkecil yang memungkinkan (minimasi input), dengan demikian input merupakan sesuatu yang dapat dikontrol; (2) Model orientasi output (output-oriented model) yaitu model dimana setiap DMU diharapkan memproduksi sejumlah output terbesar yang memungkinkan dengan sejumlah input tertentu (maksimasi output), dengan demikian output merupakan sesuatu yang dapat dikontrol; dan (3) Model orientasi dasar (baseoriented model) yaitu model dimana setiap DMU diharapkan memproduksi dengan kondisi gabungan optimal antara input dan output, dengan demikian input dan output merupakan sesuatu yang dapat dikontrol (Charnes, Roussea \& Semple, 1996).

Nilai efisiensi teknis pada penelitian ini didasarkan pada pendekatan output oriented (maksimalisasi output) dan model VRS (variable returns to scale) dengan pertimbangan bahwa produksi ikan bandeng belum beroperasi pada skala yang optimal karena adanya kelebihan penggunaan faktor-faktor input yang digunakan. Hal ini terlihat pada besarnya nilai slack pada input yang digunakan. Khususnya pada penggunaan tenaga kerja dan besarnya jarak laut dengan tambak.

\section{Analisis Regresi Linear Berganda}

Analisis kuantitatif menekankan analisisnya pada data-data berupa angka yang diolah dengan metode statistika. Dengan metode kuantitatif akan diperoleh signifikasi perbedaan kelompok atau signifikansi hubungan antara variabel yang diteliti (Azwar, 2001). Metode kedua yang digunakan untuk menganalisis data pada penelitian ini adalah dengan menggunakan estimasi regresi linier berganda untuk menganalisis fungsi produksi Cobb-Douglass. Untuk mengetahui pengaruh faktor jumlah benih bandeng, luas tambak, jumlah tenaga kerja, dan jarak tambak dengan laut terhadap produksi Ikan Bandeng Kabupaten Pati, dinyatakan dalam fungsi sebagai berikut:

$\operatorname{Prod}=\mathrm{f}(\mathrm{Bb}, \mathrm{Lt}, \mathrm{Tk}, \mathrm{Jar})$ berikut:

Fungsi Cobb-Douglass adalah sebagai

Prod $=\beta_{0} \mathrm{Bb}^{\beta 1} \mathrm{Lt}^{\beta 2} \mathrm{Tk}^{\beta 3} \mathrm{Jar}^{\beta 4}$

Untuk menghitung elastisitas dari masingmasing variabel bebas ke variabel terikat, koefisien regresi di atas ditransformasikan ke dalam bentuk logaritma natural (In) dan diperoleh persamaan sebagai berikut:

$$
\begin{aligned}
& L n \text { Prod }=L n \beta 0+\beta 1 L n_{-} B b+\beta 2 L n_{-} L t+ \\
& \beta 3 L n_{-} T k+\beta 4 L n_{-} J a r+\mu
\end{aligned}
$$

\section{Keterangan/Remark:}

$$
\begin{aligned}
\text { Prod }= & \text { Poduksi ikan bandeng }(\text { Ton/panen }) / \text { Milkfish } \\
& \text { Productions }(\text { Tons/haevest }) \\
\mathrm{Bb}= & \text { Jumlah benih bandeng (ekor)/ Number of } \\
& \text { milkfish seeds (tail) } \\
\mathrm{Lt}= & \text { Luas tambak }(\mathrm{Ha}) / \text { Area of Ponds }(\mathrm{Ha}) \\
\mathrm{Tk}= & \text { Jumlah tenaga kerja(orang)/Labors(Persons) } \\
\mathrm{Jar}= & \text { Jarak tambak dengan laut }(\mathrm{Km}) / \text { Distance } \\
& \text { Ponds from Sea }(\text { Km) } \\
\beta_{0}= & \text { Intersep/Intercept } \\
\mathrm{Ln}= & \text { Logaritma natural/Natural logaritm }
\end{aligned}
$$




\section{HASIL DAN PEMBAHASAN}

\section{a. Efisiensi Teknis Pembudidaya Ikan Bandeng}

Pengukuran tingkat efisiensi usaha tambak ikan bandeng menggunakan analisis Data Envelopment Analysis (DEA). Analisis DEA merupakan salah satu bentuk analisis data non parametrik yang menghitung tingkat efisiensi masing-masing kelompok unit produksi yang tergabung dalam Decision Making Units (DMUs). seperti dikatakan sebelumnya bahwa penelitian ini menghitung tingkat efisiensi tiap DMU dengan pendekatan out put (output oriented) pada skala Variable Return to Scale (VRS). Pendekatan output oriented merupakan pendekatan dimana tiap-tiap DMU akan mengoptimalkan jumlah output tanpa menambahkan input. DEA Model VRS merupakan model DEA memiliki karakteristik teknologi bersifat variable (varying) return to scale, dimana tiap-tiap DMU dimungkinkan untuk beroperasi pada kondisi yang tidak optimal. Keadaan tidak optimal ini bisa disebabkan misalnya adanya keterbatasan modal, hambatan pada faktor cuaca, adanya gangguan hama dan penyakit, dan lain-lain. Berdasarkan pertimbangan di atas, maka sangat dimungkinkan tiap DMU akan bekerja pada pada increasing return to scale atau bahkan decresing return to scale.

Model VRS juga lebih menunjukkan kesesuaian dengan kondisi yang sebenarnya dari DMU-DMU (dalam observasi) dimana tidak semua DMU beroperasi pada skala optimal (constant), karena adanya keterbatasan-keterbatasan yang dimiliki oleh masing-masing DMU. Sedangkan pendekatan output (output oriented) yaitu model dimana setiap DMU diharapkan memproduksi sejumlah output terbesar yang memungkinkan dengan sejumlah input tertentu (maksimasi output), dengan demikian output merupakan sesuatu yang dapat dikontrol. Dalam DEA ini dilakukan pengujian terhadap $80 \mathrm{DMU}$, di mana keseluruhan DMU tersebut merupakan rumah tangga pembudidaya ikan bandeng selaku unit produksi, berikut adalah hasil analisa pengolahan data dilakukan dengan aplikasi Maxdea terhadap 80 DMU dalam penelitian ini dapat dilihat pada Tabel 1.

Berdasarkan hasil pengolahan Maxdea dari 80 DMU pembudidaya tambak di Kabupaten Pati, diperoleh nilai Technical Effiecency (TE) tertinggi adalah 1,nilai terendahnya adalah 0,474 dan rata-rata nilai TE dari seluruh sampel bembudi daya bandeng di Kabupaten Pati adalah 0,741. Nilai TE semakin mendekati nilai 1 maka DMU tersebut dinyatakan telah efisien dan semakin menjauhi nilai 1 maka DMU dinyatakan semakin tidak efisien. Berdasarkan hasil tersebut dikategorikan nilai $\mathrm{TE}=1$ dikategorikan efisien, nilai $\mathrm{TE}$ antara 1 sampai dengan rata-rata $(0,741 \leq \mathrm{TE}<1)$ dikategorikan tingkat efisien baik dan nilai TE dibawah rata-rata (TE $<0,741)$ dikategorikan sebagai tingkat efisiensi rendah.

Suatu metode produksi dapat dikatakan lebih efisien dari metode lainnya jika metode tersebut menghasilkan output yang lebih besar pada tingkat korbanan yang sama atau suatu metode produksi yang menggunakan korbanan yang paling kecil, juga dikatakan lebih efisien dari metode produksi lainnya, jika menghasilkan nilai output yang sama besarnya (Kurniawan, 2008). Produsen dikatakan efisien secara teknis jika dan hanya jika tidak mungkin lagi memproduksi lebih banyak output dari yang telah ada tanpa mengurangi sejumlah output lainnya atau dengan menambah sejumlah input tertentu (Kumbakhar dan Lovell, 2000)

Berdasarkan Tabel 2, diketahui bahwa sebagian besar pembudidaya bandeng di Kabupaten Pati, berada pada posisi di bawah rata-rata efiseinsi teknik. Hanya terdapat 16 pembudidaya $(20 \%)$ yang memiliki tingkat efisiensi sempurna (Perfect Efficiency)dengan nilai $T E=1$. Hal ini menunjukkan bahwa sebagian besar pembudidaya ikan bandeng di Kabupaten Pati, masih belum optimal dalam hal penggunaan faktor-faktor inputnya. Hali ini terlihat dari besarnya

Tabel 1. Peringkat DMU Berdasarkan Nilai TE.

Table 1. DMU Ranking Based on TE Value.

\begin{tabular}{clcc}
\hline No & \multicolumn{1}{c}{$\begin{array}{c}\text { Peringkat Efisiensi/ } \\
\text { Efficiency Rank }\end{array}$} & $\begin{array}{c}\text { Jumlah DMU/ } \\
\text { Total DMUs }\end{array}$ & $\begin{array}{c}\text { Persentase/ } \\
\text { Prosentage (\%) }\end{array}$ \\
\hline 1 & Efisien/Efficient (TE = 1) & 16 & 20 \\
3 & Baik/Good $(0,741 \leq \mathrm{TE}<1)$ & 20 & 25 \\
4 & Rendah/Low $(\mathrm{TE}<0,741)$ & 44 & 55 \\
\hline
\end{tabular}

Sumber: Output DEA, diolah 2018./ Sources: DEA outputs, processed 2018. 
nilai slack khususnya pada penggunaan input tenaga kerja dan besarnya jarak tambak dari laut (lampiran 1).

Setelah dilakukan pengelompokan DMU ke dalam beberapa kategori efisiensi, dilakukan pula pengelompokan efisiensi skala pembudidaya ikan bandeng berdasarkan variabel luas lahan yang digarap. Dalam penelitian ini, pembudidaya dengan luas lahan di bawah $5 \mathrm{Ha}(<5 \mathrm{Ha})$ digolongkan dalam pembudidaya skala kecil, pembudidaya dengan luas lahan antara $5 \mathrm{Ha}$ sampai dengan $10 \mathrm{Ha}(5 \mathrm{Ha} \leq \mathrm{x}<10 \mathrm{Ha}$ ) tergolong pembudidaya skala sedang dan pembudidaya dengan luas lahan di atas 10 ha digolongkan dalam pembudidaya skala besar. Dalam penelitian ini terdapat 34 pembudidaya skala kecil, 32 pembudidaya skala sedang dan 14 pembudidaya skala besar.

Pembudidaya bandeng skala kecilmenengah cenderung memiliki tingkat efisiensi yang rendah, hal ini terlihat dengan prosentasi TE di bawah rata-rata yang mencapai 55,88\% dan $56 \%$. Sedangkan pada pembudidaya bandeng skala besar dengan luas lahan $>10 \mathrm{Ha}$ memiliki $50 \%$ pembudidaya yang berada di bawah rata-rata. Penyebab inefisiensi pembudidaya bandeng di Kecamatan Juwana, sebagian besar adalah penggunaan input yang terlalu besar, terutama pada variabel tenaga kerja dan jarak antar tambak dengan laut yang terlalu jauh. Hal ini menyebabkan pembudidaya tambak bandeng di Kabupaten
Pati, terbebani biaya produksi untuk membayar tenaga kerja dan memperbaiki saluran air yang menghubungkan tambak dengan laut.

Berdasarkan analisis DEA sebagian besar pembudidaya ikan bandeng baik skala kecil, menengah maupun sedang, masih memiliki tingkat efisiensi yang rendah. Hal ini dikarenakan bahwa produksi ikan bandeng pada periode Juni-Juli 2018 di Kabupaten Pati memang mangalami penurunan, yang dikarenakan faktor alam yakni curah hujan yang tinggi pada tahun 2018. Curah hujan rata-rata 16-20 hari perbulan sehingga mempengaruhi tingkat kadar garam air tambak yang pada akhirnya mempengaruhi kualitas ikan bandeng. Kualitas bandeng yang tidak memenuhi standar pasar, mengakibatkan pembeli akan mengurangi jumlah permintaan ikan bandeng. Untuk mengantisipasi hal tersebut, pembudidaya ikan bandeng mengurangi jumlah benih yang ditebar pada bukan JanuariFebruari, sehingga mempengaruhi jumlah produksi ikan bandeng pada periode panen Juni-Juli 2018.

Dengan skala tambak yang lebih luas, penggunaan kedua variabel tersebut dapat dimaksimalkan karena dengan luas lahan yang memadai, benih bandeng yang ditebar lebih banyak, penggunaan tenaga kerja juga bisa lebih optimal. Dengan demikian, tidak lagi terdapat input yang terbuang jika skala tambak diperluas sedangkan input tersebut digunakan dalam jumlah yang relatif tetap. Pada skala tambak yang luas, maka

\section{Tabel 2. Peringkat Efisiensi Berdasar Skala Usaha Budidaya.} Table 2. Efficiency Rating Based on Farmer's Scale.

\begin{tabular}{|c|c|c|c|}
\hline No & $\begin{array}{l}\text { Peringkat Efisiensi/ } \\
\text { Efficiency Rank }\end{array}$ & $\begin{array}{l}\text { Skala Usaha Budidayal } \\
\text { Scale Farming Bussines }\end{array}$ & $\begin{array}{c}\text { Persentase/ } \\
\text { Prosentage (\%) }\end{array}$ \\
\hline \multirow[t]{3}{*}{1} & \multirow[t]{3}{*}{ Efisien/Efficient(TE = 1) } & $\begin{array}{l}\text { Besar/Big : } 5 \text { pembudidaya dari } 14 \\
\text { pembudidaya/ } 5 \text { farmers from } 14 \text { farmers }\end{array}$ & 35.71 \\
\hline & & $\begin{array}{l}\text { Sedang/Middle : } 4 \text { pembudidaya dari } 32 \\
\text { pembudidaya/4 farmers from } 32 \text { farmers }\end{array}$ & 12.50 \\
\hline & & $\begin{array}{l}\text { Kecil/Small: } 7 \text { pembudidaya dari } 34 \\
\text { pembudidaya/ } 7 \text { farmers from } 34 \text { farmers }\end{array}$ & 20.58 \\
\hline \multirow[t]{3}{*}{2} & \multirow[t]{3}{*}{ Baik/ Good $(0,741 \leq$ TE < 1) } & $\begin{array}{l}\text { Besar/Big:2 pembudidaya dari } 14 \\
\text { pembudidaya/ } 2 \text { farmers from } 14 \text { farmers }\end{array}$ & 7.14 \\
\hline & & $\begin{array}{l}\text { Sedang/Middle: } 10 \text { pembudidaya dari } 32 \\
\text { pembudidaya/10 farmers from } 32 \text { farmers }\end{array}$ & 15.63 \\
\hline & & $\begin{array}{l}\text { Kecil/small: } 8 \text { pembudidaya dari } 34 \\
\text { pembudidaya/ } 8 \text { farmers from } 34 \text { farmers }\end{array}$ & 14.71 \\
\hline \multirow[t]{3}{*}{4} & \multirow[t]{3}{*}{ Rendah/ Low $($ TE $<0,741)$} & $\begin{array}{l}\text { Besar/Big: } 7 \text { pembudidaya dari } 14 \\
\text { pembudidaya/ } 7 \text { farmers from } 14 \text { farmers }\end{array}$ & 50 \\
\hline & & $\begin{array}{l}\text { Sedang/Middle: } 18 \text { pembudidaya dari } 32 \\
\text { pembudidaya/18 farmers from } 32 \text { farmers }\end{array}$ & \multirow{2}{*}{$\begin{array}{l}56.25 \\
55.89\end{array}$} \\
\hline & & $\begin{array}{l}\text { Keci/Small: } 19 \text { pembudidaya dari } 34 \\
\text { pembudidaya/ } 19 \text { farmers from } 34 \text { farmers }\end{array}$ & \\
\hline
\end{tabular}


benih bandeng yang ditebar bisa semakin banyak, penggunaan input tenaga kerja juga lebih optimal. sedangkan terkait dengan jarak tambak dengan laut yang terlalu besar diatasi dengan penggunaan saluran irigasi yang lancar. Artinya tenaga kerja yang digunakan tidak hanya digunakan untuk mengolah lahan tambak, namun juga dipekerjakan untuk mengolah saluran irigasi tambak. Sehingga aspek kendala jarak tambak dengan laut dapat diatasi.

\section{b. Analisis Regresi Linear Berganda}

Berdasarkan Tabel 4, secara simultan seluruh variabel dalam penelitian ini, yaitu jumlah benih, luas lahan, tenaga kerja dan jarak laut dengan tambak mempengaruhi produksi ikan bandeng di Kabupaten Pati. Hal ini ditunjukkan dengan nilai probabilitas uji $F$ sebesar 0,000 . Adapun secara parsial pengaruh masing-masing variabel dijelaskan di bawah ini.

Benih bandeng memiliki pengaruh positif dan signifikan terhadap produksi bandeng di Kabupaten Pati. Hal ini didasarkan hasil analisis regresi linier berganda nilai probabilitas uji $t$ terhadap benih bandeng adalah 0,0000 yang berarti bahwa variabel benih bandeng memiliki pengaruh terhadap produksi ikan bandeng. Dari hasil estimasi didapatkan koefisien regresi variabel benih sebesar 0,976 di mana koefisien regresi tersebut sekaligus menunjukkan elastisitas input jumlah benih bandeng. Maka dapat diartikan bahwa jika dilakukan penambahan input benih bandeng sebesar $1 \%$, jumlah produksi bandeng akan mengalami kenaikan sebesar $0,976 \%$ dengan asumsi bahwa variabel lainnya dianggap konstan.

Benih bandeng memegang peranan penting dalam produksi ikan bandeng di Kecamatan Juwana. Benih ikan bandeng atau masyarakat setempat mengenal dengan istilah nener, diperoleh pembudidaya dari pemasok. Para pembudidaya di Kecamatan Juwana lebih memilih membeli nener dari pemasok, dibandingkan dengan melakukan pembenihan sendiri. Hal ini dikarenakan proses pembenihan nener lebih rumit dibandingkan dengan pembesaran. Rata-rata dalam $1 \mathrm{Ha}$ luas lahan ditaburkan 10.000 ekor nener. Secara teori,

Tabel 3. Variabel Regresi Linear Berganda.

Table 3. Variables Linear Regression.

\begin{tabular}{lcrr}
\hline \multicolumn{1}{c}{ Variabel/Variables } & Rata-rata/Mean & Minimum & Maksimum \\
\hline Produksi (Prod) & 6,755 & 0.75 & 17 \\
Benih Bandeng (Bb) & 67462.5 & 6,700 & 200,000 \\
Luas Tambak (Lt) & 6.22 & 1 & 15 \\
Tenaga kerja (Tk) & 28,087 & 22 & 37 \\
Jarak laut ke Tambak (Jarak) & 6.97 & 0.75 & 13 \\
\hline
\end{tabular}

Tabel4. Hasil Regresi OLS.

Table 4. OLS Regression's Result.

\begin{tabular}{lcccc} 
& Beta & Std. Error & t-Statistic & Prob. \\
\hline C & -1.021 & 0.556 & -1.834 & 0.071 \\
Ln_Bb & 0.977 & 0.066 & 14.646 & 0.000 \\
Ln_LI & 0.119 & 0.058 & 2.044 & 0.044 \\
Ln_Tk & 0.036 & 0.051 & 0.719 & 0.473 \\
Ln_Jar & -0.177 & 0.034 & -5.143 & 0.000 \\
\hline F =338,97 & & & \\
Prob. =0.0000 & & & \\
$\mathrm{R}^{2}=0,947:$ Adjusted $\mathrm{R}^{2}=0,944$ & & & \\
\hline
\end{tabular}

Sumber: Output Eviews, 2018./Source: Eviews output, 2018.

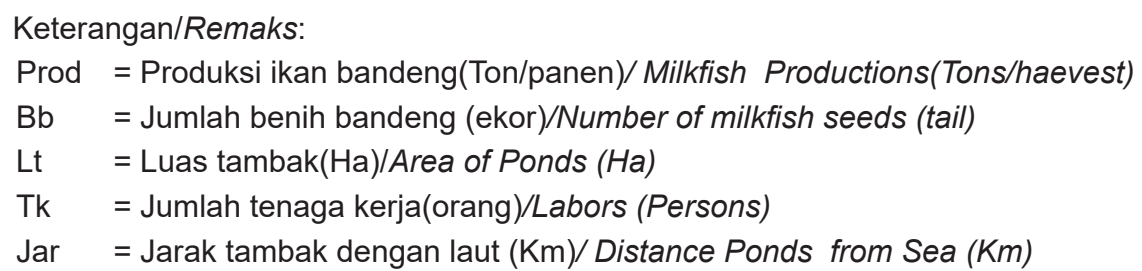


dalam $1 \mathrm{Ha}$ boleh ditabur nener 10.000-30.000 ekor nener. Tetapi masyarakat Kecamatan Juwana lebih memilih menabur nener pada tingkat minimum yakni 10.000 ekor per herktar. Bahkan ada yang hanya menabur 7.500-8.000 ekor saja setiap hektarnya. Hal ini dikarenakan untuk memberikan ruang tumbuh bagi pembesaran bandeng, sehingga ikan bandeng yang dihasilkan akan lebih optimal.

Penelitian terhadulu (Sumiratin, 2012) yang mengkaji tentang analisis keuntungan bandeng di Gresik menyatakan hal yang sama, bahwa penggunaan benih ikan bandeng memberikan pengaruh yang signifikan dan positif terhadapa produksi ikan bandeng di Gresik, yang pada akhirnya akan memperbesar pendapatan pembudidaya bandeng di Gresik. Namun penelitian (Faiq, 2012) menyatakan hal yang berbeda yaitu jumlah benih yang ditebar di lahan tidak memberikan pengaruh yang signifikan. Hal ini dikarenakan kurangnya benih yang ditebar di lahan tambak yang diakibatkan oleh keterbatasan biaya pembelian benih.

Luas lahan memiliki pengaruh yang signifikan dan positif terhadap produksi ikan bandeng di Kabupaten Pati. Berdasarkan hasil analisis regresi linier berganda nilai probabilitas uji $t$ terhadap $\mathrm{X} 2$ adalah 0,044 . Dimana probabilitasnya lebih kecil dari alpha $(\alpha) 5 \%$ atau 0,05 . Luas lahan memiliki koefisien sebesar 0,119 di mana koefisien regresi tersebut sekaligus menunjukkan elastisitas input luas lahan tambak bandeng. Berdasarkan hasil regresi tersebut, maka dapat diartikan bahwa jika dilakukan penambahan input luas lahan tambak bandeng sebesar $1 \%$, jumlah produksi bandeng akan mengalami kenaikan sebesar 0,119\% dengan asumsi bahwa variabel lainnya dianggap konstan.

Pierluigi Toma (Toma, Miglietta, Zurlini, Valente \& Petrosillo, 2017) menyatakan hal yang sama bahwa luas lahan yang dibarengi dengan sistem pengolahan yang baik akan memberikan dampak yang positif terhadap produksi pertanian di negara-negara Uni Eropa. Sejalan dengan Toma, Endang (Sumiratin, 2012) juga menyatakan bahwa luas lahan tambak sangat berpengaruh positif dan signifikan terhadap produksi bandeng di Gresik. Hasil yang berbeda diungkapkan (Deng, 2018) bahwa luas lahan tidak berpengaruh pada produktivitas pertanian di Shandong, China. Sejalan dengan Xiangzheng, penelitian Hasan Faiq (Faiq, 2012) bahwa luas lahan tidak berkorelasi signifikan terhadap produksi tambak di Kelurahan Tugu Kota Semarang, yang dikarenakan belum optimalnya pengolahan lahan tambak.

Jarak tambak dengan laut memiliki koefisien $-0,17$. Artinya penambahan faktor jarak lokasi tambak dengan laut sebesar $1 \%$, akan menyebabkan penurunan produksi sebesar $17 \%$. Dengan kata lain, semakin besar jarak lokasi tambak dengan laut, maka produksi bandeng akan semakin berkurang. Jarak tambak dengan laut di Kecamatan Juwana memegang peranan penting dalam penelitian ini. Jarak ini memberikan implikasi ketersediaan kandungan garam air laut pada tambak. Ketersediaan air laut berkaitan dengan tingkat kadar garam/ salinitas air. Semakin jauh jarak yang ditempuh air laut menuju tambak, maka kadar garam akan berkurang. Terlebih dengan saluran air laut ke tambak yang tidak lancar, akan semakin mempengaruhi produksi bandeng. Hal ini dikarenakan pengaruh sifat fisik permeabitias tanah, atau kemampuan tanah dalam menyerap air yang dilaluinya (Hakim, 1986). Peneliti mengaitkan aspek jarak tambak ke laut sebagai kelancaran irigasi dan manajemen air. Penelitian Raheli, et al. (2007) menemukan bahwa sistem irigasi yang baik akan menentukan produksi pada pertanian tomat. Sejalan dengan hal ini manajemen air yang baik juga akan turut menentukan tingkat produksi perikanan di Malaysia (lliyasu, 2016). Dampak secara ekonomi adalah pembudidaya bandeng yang memiliki tambak jauh dari laut harus mengeluarkan biaya produksi lebih besar, dibandingkan dengan pembudidaya yang lokasinya lebih dekat dengan laut.

Aspek tenaga kerja tidak memiliki pengaruh yang signifikan terhadap produksi ikan bandeng di Kabupaten Pati. Analisa ketenagakerjaan dalam pertanian sering dikaitkan dengan tahap-tahap pekerjaan yang diperlukan dalam usaha pertanian itu sendiri. Informasi semacam itu sangat penting untuk menentukan alokasi sebaran penggunaan tenaga kerja selama proses produksi, sehingga pada kegiatan tertentu tidak terjadi kekurangan atau kelebihan tenaga kerja (Soekartawi, 1996). Pada kasus Penggunaan tenaga kerja yang tidak berpengaruh secara signifikan terhadap produksi bandeng di Kabupaten Pati dikarenakan pembudidaya bandeng terdapat kelebihan penggunaan tenaga kerja. Kelebihan penggunaan tenaga kerja ini dikarenakan perekrutan tenaga kerja masih bersifat kekeluargaan. Jadi pemanfaatan tenaga kerja lebih dikarenakan 
adanya hubungan keluarga antara pembudidaya tambak dengan pekerja.

Penelitian (Situmorang, 2013) pada produksi jagung di Kabupaten Dairi Sumatera Utara ditemukan bahwa aspek tenaga kerja tidak signifikan dikarenakan kelebihan jumlah tenaga kerja yang digunakan. Penggunaan tenaga kerja yang tidak signifikan juga diperoleh pada penelitian produksi tambak bandeng di Gresik. Penggunaan aspek tenaga kerja yang terlampau besar menyebabkan pengaruh yang tidak signifikan. (Sumiratin, 2012).

Pada penelitian ini penulis tidakmenggunakan variabel pakan sebagai variabel independen, dikarenakan penulis lebih memandang budidaya bandeng secara ekonomis. Namun demikian, variabel pakan dimasukkan dalam analisis pendapatan pembudi daya bandeng sebagai variabel biaya produksi.

Berdasarkan hasil Regresi Cobb Douglas diperoleh persamaan sebagai berikut :

$$
\begin{aligned}
& \text { Ln } Y=-1,021+0,976 L n_{-} B b+0,119 L n_{-} L t+0,036 \\
& L n \_T k-0,177 \text { Ln_Jar }
\end{aligned}
$$

Return to scale merupakan suatu keadaan di mana output produksi yang berubah sebagai respon adanya perubahan yang proporsional dari seluruh input produksi. Pada fungsi Cobb-Douglas, return to scale diketahui melalui penjumlahan koefisien regresi setiap variabel independen yang signifikan. Adapun hasil return to scale dalam penelitian ini adalah sebagai berikut:

Return to Scale : $\beta_{1}+\beta_{2}+\beta_{3}-\beta_{4}=0,976+0,119+$ $0,036-0,177=0,954$

Return to Scale sebesar 0,954 menjelaskan bahwa penambahan input faktor produksi sebesar 1 persen akan memberikan peningkatan pada output sebesar $0,954 \%$. Hal ini juga menunjukkan bahwa nilai Return to Scale $<1$. Atau berada pada kondisi Decreasing Return To Scale. Kondisi ini menyatakan bahwa penambahan faktor input akan menghasilkan penambahan ouputyang lebih rendah (Case, 2007). Hal banyak terjadi pada produksi pertanian dan perikanan yang sangat bergantung dalam kondisi alam. Seperti banyaknya curah hujan, pemanfaatan lahan yang belum optimal, dan saluran irigasi yang kurang lancar sehingga saluran air laut ke tambak tidak bisa optimal. Hasil ini juga senada dengan perhitungan efisiensi dengan pendekatan DEA dimana kondisi pembudidaya di Kabupaten Pati, sebagian besar masih berad di bawah rata-rata. Atau memiliki tingkat efisiensi yang rendah. Dimana sebagian besar sumber in efisiensi ada pada penggunaan tenaga kerja dan jarak tambak dan laut yang terlampau besar.

Rerata produksi ikan bandeng pembudidaya bergantung luas lahan tambak yang diusahakan dan intensitas panen yang dilakukan. Akan tetapi produksi tinggi tidak selalu berkorelasi positif dengan pendapatan, karena harga bandeng sangat ditentukan oleh permintaan pasar dan kesepakatan harga dengan para tengkulak dalam rantai distribusikan bandeng.

Hasil survei menunjukkan bahwa $60 \%$ pembudidaya ikan bandeng mengelola lahan milik sendiri, namun $40 \%$ lainnya tidak memiliki lahan sendiri sehingga melakukan sewa lahan dengan biaya sewa yang bervariasi sesuai dengan luas lahan yang disewa. Biaya sewa lahan Rp12.000.000 per tahun. Berikut adalah perhitungan analisis pendapatan pembudidaya bandeng di Kecamtan Juwana dengan asumsi rata-ata produksi 6,8 Ton/produksi pada luas lahan rata-rata $6 \mathrm{Ha}$, dan penggunaan benih rata-rata 67.000 ekor serta tenaga kerja 28 orang

Harga bandeng di pasar sangat fluktuatif bergantung dengan permintaan pasar. Adapaun harga jual bandeng yang tertera di atas adalah harga jual bandeng pada saat musim panen bulan Juni 2018. Berdasarkan perhitungan di atas, pembudidaya bandeng memperoleh keuntungan sebesar Rp56.280.000 dalam jangka waktu 6 bulan atau sebesar Rp9.380.000 per bulan. Nilai tersebut terbilang sangatbesar, mengingatUMR diKabupaten Pati hanya Rp1.350.000/bulan. Usaha tambak bandeng di Kecamatan Juwana bisa dijadikan sebagai mata pencaharian utama, walaupun pada prakteknya sebagian besar pembudidaya bandeng di Juwana menjadikan tambak bandeng sebagai usaha sampingan, karena mereka sebagian besar masih bekerja baik di sektor swasta maupun sektor pemerintah.

Berdasarkan analisis DEA pada penelitian ini yang menggunakan pendekatan outputoriented (maksimalisasi output) dan model VRS (variable returns to scale) diketahui bahwa sumber inefisiensi terbesar adalah faktor tenaga kerja dan jarak antara laut dengan tambak yang besar. Hal ini terlihat pada banyaknya slack pada variabel tenaga kerja dan jarak laut dengan tambak (lampiran 1). 
Tabel 5. Analisis Usaha Budidaya Bandeng.

Table 5. Analysis of Milkfish Farming Bussines.

\begin{tabular}{|c|c|}
\hline Aspek/Aspect & Nilai (Rp)/Value (IDR) \\
\hline \multicolumn{2}{|l|}{ a. Biaya Produksi Tetap/Fixed Cost } \\
\hline Sewa lahan/Cost Of Renting Land $6 \mathrm{Ha} \times \mathrm{Rp} 6,000,000$ & $36,000,000$ \\
\hline Penyusutan perlengkapan tambak/Cost Of Depreciation & 400,000 \\
\hline Total biaya tetap/Total Fixed Cost & $36,400,000$ \\
\hline \multicolumn{2}{|l|}{ b. Biaya Produksi Variabel/ Variable Cost } \\
\hline Benih / Milkfish Seedlings $=67,000$ ekor $\times$ Rp20 & $1,340,000$ \\
\hline Pupuk/ Fertilizer= $6 \mathrm{Ha} \times 2$ kw x Rp.125,000 & $1,500,000$ \\
\hline Pelet $/$ Pellet $=6,8$ ton $/ 2 \times 7,000 \times 1,000$ & $23,800,000$ \\
\hline Tenaga kerja/ Labors $=28$ orang $\times$ Rp110,000 & $3,080,000$ \\
\hline Muritan/ Muritan Labor(10\% x hasil produksi) & $13,600,000$ \\
\hline Total Biaya Variabel/ Total Variable cost & $43,320,000$ \\
\hline Total Biaya/ Total Cost $(a+b)$ & $79,720,000$ \\
\hline \multicolumn{2}{|l|}{ c. PendapatanPembudidaya/ Farmer's Income } \\
\hline Hasil panen/ Harvest Income $=6,8$ ton $\times 1,000 \mathrm{~kg} \times \mathrm{Rp} 20,000$ & $136,000,000$ \\
\hline $\begin{array}{l}\text { d. Total Pendapatan Pembudidaya/ Total Farmer's Income } \\
\text { (Pendapatan/ Income- biaya/cost) }\end{array}$ & $56,280,000$ \\
\hline
\end{tabular}

Slack ini menunjukkan bahwa saat ini penggunaan tenaga kerja dan jarak laut dengan tambak terlampau besar. Sehingga berdasarkan analisis DEA penggunaan tenaga kerja dan jarak laut dengan tambak perlu dikurangi. Di sisi lain hasil analisis OLS mengetengahkan bahwasannya penggunaan benih dan luas lahan berdampak signifikan positif terhadap produksi bandeng, sedangkan jarak laut dengan tambak berdampak signifikan negatif. Berdasarkan kedua hasil analisa tersebut, maka jarak laut dengan tambak menjadi salah satu kendala yang harus diperhatikan.

\section{KESIMPULAN DAN REKOMENDASI KEBIJAKAN}

\section{Kesimpulan}

Tingkat efisiensi teknis pada pembudidaya bandeng di Kabupaten Pati, menunjukkan bahwa sebagian besar pembudidaya bandeng masih belum efisien. Hal tersebut dikarenakan penggunaan tenaga kerja yang terlampau besar dan jarak lokasi tambak dengan laut yang terlampau jauh. Nilai return to scale yang dicapai menunjukkan bahwa pembudidaya bandeng di Kabupaten Pati berada pada kondisi decreasing return to scale, yang dikarenakan pembudidaya bandeng masih sangat bergantung pada alam, pemanfaatan lahan yang belum optimal, dan saluran irigasi yang kurang lancer sehingga saluran air laut ke tambak tidak bias optimal. Seluruh variable independen yaitu luas tambak, jumlah benih, tenaga kerja dan jarak tambak dengan laut, berpengaruh secara simultan terhadap variabel dependen, yaitu jumlah produksi bandeng. Namun secara parsial variabel tenaga kerja tidak memiliki pengaruh terhadap produksi bandeng Kabupaten Pati. Variabel yang memiliki pengaruh positif dan signifikan diantaranya adalah jumlah benih dan luas lahan tambak. Jarak lokasi tambak dengan laut berpengaruh negatif dan signifikan. Sehingga perlu langkah alternatif untuk mengatasi kendala jarak antara laut dengan tambak. Langkah yang perlu ditempuh adalah dengan pengerukan kembali sungai yang menghubungkan laut dengan tambak.

Secara ekonomis, usaha tambak bandeng di Kabupaten Pati masih memberikan keuntungan. Hal ini terlihat pada analisis pendapatan pembudidaya ikan bandeng yang mampu menghasilkan rata-rata Rp9.380.000 per bulan jauh melampoi UMR Kabupaten Pati yang sebesar Rp1.350.000.

\section{Rekomendasi Kebijakan}

Peningkatan efisiensi pada pembudidaya bandeng dapat dilakukan dengan berfokus pada penggunaan input penggunaan benih bandeng, pengoptimalan lahan dan mengatasi kendala jarak laut dengan tambak. Disamping itu berdasarkan analisis DEA dimana saat ini pembudidaya ikan bandeng di Kabupaten Pati, masih berlebihan dalam penggunaan tenaga kerja, sehingga perlu dikurangi. Di samping itu penggunaan tenaga kerja 
yang terlampau besar justru akan membebani pembudidaya itu sendiri. Adapun terkait jarak laut dengan tambak yang terlampau besar, dapat dilakukan dengan memperlancar aliran sungai yang menyalurkan air laut ke tambak. Pada saat penelitian ini dilaksanakan sungai penghubung laut dengan tambak sudah mengalami pendangkalan, sehingga pemerintah perlu turun tangan. Hal ini dilakukan dengan pengerukan sungai yang menyalurkan air laut ke tambak secara berkala. Sehingga asupan air laut ke tambak lebih lancar. Saat ini di Kabupaten Pati sudah mulai dikembangkan budidaya ikan bandeng air tawar, namun hasilnya masih belum optimal. kualitas ikan bandeng air tawar, belum sebagus bandeng air payau, sehingga perlu penelitian lebih lanjut.

Peningkatan pengetahuan pembudidaya perlu dilakukan dengan cara penyuluhan secara intensif terhadap pembudidaya. Penyuluhan perikanan difokuskan pada pengelolaan lahan secara intensif dan pegaturan kadar garam pada lahan. Hal ini dikarenakan pengaturan kadar garam merupakan salah satu faktor penting dalam proses pembesaran bandeng agar diperoleh bandeng yang manis, gurih dan tidak berbau lumpur. Selama ini pembudidaya hanya mengandalkan kebiasaan (rutinitas) turun temurun saja. Di sisi lain seiring dengan perkembangan jaman, kondisi alam sudah berubah. Sehingga pembudidaya harus mengetahui langkah yang harus diambil untuk menghadapi perubahan kondisi alam.

\section{UCAPAN TERIMA KASIH}

Terima kasih kami ucapkan kepada para dosen pembimbing, responden pembudidaya bandeng di Kabupaten Pati, dan Pemerintah Kabupaten Pati, khususnya Dinas Perikanan dan Kelautan Kabupaten Pati.

\section{DAFTAR PUSTAKA}

Abbam, A. (2009). Comparative Study of Technical Efficiency of Pineapple Exporters and Non Exporters in the Central Region of Gana. University of Cape Coast Ghana.

Achaw, M. A. (2010). The Impact of Large-Scale Pineapple Companies on Rural Livelihoods in Akuapim South Municipality of Ghana. University of Oslo Norwegia.

Alexander, J. W. (1954). The Basic-nonbasic Concept Of Urban Economic Functions. Economic Geography, 30, 246-261.
Ananda, C. F. (2017). Pembangunan Ekonomi Daerah Dinamika dan Strategi Pembangunan (1st ed.). Indonesia: UB Press.

Arsyad, L. (1999). Ekonomi pembangunan. Yogyakarta : STIE YKPN.

Azwar, S. (2001). Metode Penelitian. Yogyakarta: Pustaka Pelajar

Bendavid-Val, A. (1991). Regional and Local Economics Analysis for Practitioners. New York: Priager.

Case, K. E. (2007). Prinsip-Prinsip ekonomi (edisi pert). Jakarta: Erlangga

Charnes, A., Roussea, J. J., \& Semple, J. H. (1996). Sensitivity and stability of efficiency classifications in data envelopment analysis. Journal of Productivity Analysis, 7(1), 5-18.

Deng, X. (2018). Improving Eco-Efficiency for The Sustainable Agricultural Production: A Case Study in Shandong, China. Science Direct.

Faiq, H. (2012). Analisis Pendapatan Budidaya BAndeng Kelurahan Tugurejo Kecamatan Tugu Kota Semarang. Jurnal Unwahas.

Gay, L. R., \& Diehl, P. L. (1992). Research Methods for Business and Management. New York: MacMillan Publishing Company.

Hakim. (1986). Dasar-Dasar Ilmu Tanah. Lampung: Universitas LAmpung.

Hallam, D., \& Machado, F. (2014). Efficiency analysis with panel data: A study of Portuguese dairy farms. Oxford Journals.

Hoyd, H. (1954). Development Of Economic Base Concept. Land Economics Journal, 30, 182-186.

Iliyasu, A. (2016). Evaluating contextual factors affecting the technical efficiency offreshwater pond culture systems in Peninsular Malaysia: A two-stageDEA approach. Science Direct, 3(Aqua Culture Reprt), $13-17$.

Institute for Management Development. (2014). The World Competitiveness Yearbook. IMD World Competitiveness Center. Switzerland: Switzerland.

Kothari, C. R. (2004). Research Methodology Methods and Techniques (2nd ed.). New Delhi: New Ages International Publisher.

Kumbakhar, S. C., \& Lovell, C. A. K. (2000). Stochastic Frontier Analysis. Melburne: Cambridge University Press.

Kuncoro, M. (2014). Otonomi Daerah: Menuju Era Baru Pembangunan Daerah (3rd ed.). Jakarta: Erlangga.

Kurniawan, A. Y. (2008). Analisis Efisiensi Ekonomi dan Daya Saing Usaha tani Jagung Pada Lahan Kering di Kabupaten Tanah Laut Kalimantan Selatan. Institut Pertanian Bogor. 
Morissan. (2015). Metode Penelitian Survei. Jakarta: Prenadamedia Gruop.

Muliawan, I., \& Firdaus, M. (2018). Nilai Ekonomi Ekosistem Terumbu Karang di Taman Wisata Peraiaran Kapoposang, Sulawesi Selatan Economic Value Of Coral Reef Ecosystem In The Kapoposang Marine Park Conservation, South Sulawesi. Jurmal Sosial Ekonomi Kelautan Dan Perikanan, Vol 13(No 1), 133-142.

Raheli, H., Rezaei, R. M., Jadidi, M. R., \& Mobtaker, H. G. (2017). A two-stage DEA model to evaluate sustainability and energy efficiency of tomato production. Information Processing in Agriculture, $4(4), \quad 342-350 . \quad \mathrm{https}: / /$ doi.org/10.1016/j. inpa.2017.02.004

Rifa'i, A. (2013). Pendidikan dan Efisiensi: Metode Data Envelopment Analysis. Jurnal Perspektif Bisnis, $1,1$.

Sabarno, H. (2008). Untaian Pemikiran Otonomi Daerah : Memandu Otonomi Daerah Menjaga Kesatuan Bangsa. Jakarta: Sinar Grafika.

Situmorang, H. (2013). Tingkat Efisiensi Ekonomi dan Daya Saing Usahatani Jagung di Kabupaten Dairi Provinsi Sumatera Utara. Institut Pertanian Bogor.

Soekartawi. (1996). IImu Usaha Tani dan Penelitian Untuk Pengembangan Petani Kecil. Jakarta: UI Press.

Sumiratin, E. (2012). Analisis Keuntungan dan Faktor-faktor yang Mempengaruhi Produksi Budidaya Tambak Bandeng di Ujungpangkah Kabupaten Gresik.

Tarigan, R. (2007). Ekonomi Regional, Teori dan Aplikasi (4th ed.). Yogyakarta: PT Bumi Aksara.

Toma, P., Miglietta, P. P., Zurlini, G., Valente, D., \& Petrosillo, I. (2017). A non-parametric bootstrap-data envelopment analysis approach for environmental policy planning and management of agricultural efficiency in EU countries. Ecological Indicators, 83(August), 132-143. https://doi.org/10.1016/j. ecolind.2017.07.049

World Economic Forum. (2014). The Global Competitiveness Report 2014-2015.

Zhu, X., Demeter, R. M., \& Lansink, A. O. (2008). Competitiveness of dairy farms in three countries: the role of CAP subsidies. 12Th Congress of the European Association of Agricultural Economist, (June 2014), 1-15. 
Lampiran 1. Keluaran DEA.

Appendix 1. Output DEA.

\begin{tabular}{|c|c|c|c|c|c|c|c|c|c|c|c|}
\hline \multirow{2}{*}{ DMU } & \multirow{2}{*}{ Score } & \multicolumn{4}{|c|}{ Slack Movement } & \multicolumn{4}{|c|}{ Projection } & \multirow{2}{*}{$\begin{array}{l}\text { Prop. Mov. } \\
\text { Produksi }\end{array}$} & \multirow{2}{*}{$\begin{array}{c}\text { Projection } \\
\text { Produksi }\end{array}$} \\
\hline & & Land & Benih & TK & Jarak & Land & Benih & TK & Jarak & & \\
\hline 01 & 0.9157 & 0 & 0 & -3.88 & -0.63 & 8.5 & 80000 & 26.123 & 7.87 & 1.104234 & 13.1042 \\
\hline 02 & 0.6741 & 0 & 0 & 0 & 0 & 7 & 65000 & 25 & 4.5 & 3.263217 & 10.0132 \\
\hline 03 & 1 & 0 & 0 & 0 & 0 & 8.75 & 90000 & 25 & 2.7 & 0 & 12 \\
\hline 04 & 0.8955 & 0 & -3137 & 0 & 0 & 3.2 & 32463.3 & 28 & 3 & 0.524917 & 5.02492 \\
\hline 05 & 0.8077 & 0 & 0 & 0 & -0.94 & 3 & 31500 & 26 & 5.06 & 0.892978 & 4.64298 \\
\hline 06 & 0.6995 & 0 & 0 & 0 & -1.26 & 3.2 & 32800 & 27 & 4.24 & 1.503614 & 5.00361 \\
\hline 07 & 0.6647 & 0 & 0 & 0 & -0.82 & 1.95 & 14100 & 26 & 2.68 & 0.882674 & 2.63267 \\
\hline 08 & 0.6433 & 0 & -1282 & -4.73 & 0 & 10 & 118718 & 25.273 & 6 & 5.545455 & 15.5455 \\
\hline 09 & 0.6248 & 0 & 0 & -2.87 & -6.32 & 3.3 & 25200 & 25.134 & 2.38 & 1.801583 & 4.80158 \\
\hline 10 & 0.5687 & 0 & -531.7 & 0 & -4.28 & 3.3 & 37568.3 & 27 & 4.72 & 2.275 & 5.275 \\
\hline 11 & 0.9059 & -2.01 & 0 & -9.15 & 0 & 9.9947 & 115000 & 25.846 & 9 & 1.558412 & 16.5584 \\
\hline 12 & 0.7059 & -1 & -27760 & -8.4 & 0 & 11 & 132240 & 26.6 & 8.5 & 5 & 17 \\
\hline 13 & 0.6643 & -1.21 & 0 & -6.89 & 0 & 10.789 & 130000 & 25.105 & 4 & 5.052632 & 15.0526 \\
\hline 14 & 0.6075 & 0 & 0 & 0 & 0 & 6 & 65500 & 26 & 6.5 & 3.876497 & 9.8765 \\
\hline 15 & 0.4739 & 0 & -546.7 & -0.02 & -6.39 & 3.3 & 34453.3 & 28.978 & 3.11 & 2.775 & 5.275 \\
\hline 16 & 0.5776 & 0 & 0 & -0.53 & -1.87 & 5.9 & 60000 & 25.474 & 5.33 & 4.022657 & 9.52266 \\
\hline 17 & 0.7317 & 0 & -4223 & 0 & -2.76 & 3.8 & 41676.7 & 28 & 4.24 & 1.65 & 6.15 \\
\hline 18 & 0.7423 & 0 & -2417 & -1.22 & -2.02 & 3.75 & 39883.3 & 28.778 & 3.58 & 1.5625 & 6.0625 \\
\hline 19 & 0.9474 & 0 & -5967 & -2.89 & -1.39 & 3 & 30833.3 & 29.111 & 2.81 & 0.25 & 4.75 \\
\hline 20 & 0.7273 & 0 & -1317 & -0.56 & -3.07 & 2.25 & 21783.3 & 29.444 & 2.03 & 0.9375 & 3.4375 \\
\hline 21 & 0.5676 & 0 & 0 & -11.3 & 0 & 8.75 & 95000 & 25.735 & 7.5 & 6.095254 & 14.0953 \\
\hline 22 & 0.789 & -0.58 & 0 & -9.92 & 0 & 9.9221 & 100000 & 26.078 & 8.2 & 3.208581 & 15.2086 \\
\hline 23 & 0.8678 & 0 & -38487 & -4.76 & -1.28 & 7.2 & 81513.3 & 27.244 & 7.12 & 1.6 & 12.1 \\
\hline 24 & 0.4932 & 0 & -20850 & -2 & -4.9 & 5.5 & 64150 & 26 & 7 & 4.625 & 9.125 \\
\hline 25 & 0.6948 & 0 & 0 & -0.3 & 0 & 8.5 & 80000 & 25.695 & 5.5 & 3.732869 & 12.2329 \\
\hline 26 & 0.6234 & 0 & -1733 & 0 & -4.33 & 4 & 46766.7 & 25 & 5.67 & 2.416667 & 6.41667 \\
\hline 27 & 1 & 0 & 0 & 0 & 0 & 9.5 & 10000 & 28 & 6.7 & 0 & 8.5 \\
\hline 28 & 1 & 0 & 0 & 0 & 0 & 7.5 & 80000 & 25 & 1 & 0 & 7.25 \\
\hline 29 & 0.9945 & 0 & 0 & -1.19 & 0 & 4 & 40000 & 26.814 & 2.75 & 0.033422 & 6.03342 \\
\hline 30 & 1 & 0 & 0 & 0 & 0 & 1 & 6700 & 30 & 0.75 & 0 & 1.25 \\
\hline 31 & 1 & 0 & 0 & 0 & 0 & 1.5 & 8100 & 25 & 1 & 0 & 1.75 \\
\hline 32 & 0.7923 & 0 & 0 & 0 & 0 & 8 & 90000 & 25 & 8 & 2.752238 & 13.2522 \\
\hline 33 & 0.5939 & 0 & 0 & -2.89 & -2.45 & 9 & 90600 & 26.106 & 8.55 & 5.812997 & 14.313 \\
\hline 34 & 1 & 0 & 0 & 0 & 0 & 15 & 200000 & 29 & 2.5 & 0 & 17 \\
\hline 35 & 0.7107 & -0.59 & 0 & -0.36 & 0 & 9.9115 & 100000 & 25.642 & 5.5 & 4.070982 & 14.071 \\
\hline 36 & 0.7644 & 0 & 0 & -1.16 & 0 & 7.5 & 80000 & 24.839 & 4 & 2.620106 & 11.1201 \\
\hline 37 & 0.5581 & 0 & -10383 & -1 & -0.33 & 9.5 & 109617 & 26 & 9.67 & 7.125 & 16.125 \\
\hline 38 & 0.5455 & 0 & -9933 & 0 & -3.33 & 3 & 35066.7 & 24 & 4.67 & 2.083333 & 4.58333 \\
\hline 39 & 1 & 0 & 0 & 0 & 0 & 10 & 120000 & 25 & 4.5 & 0 & 15 \\
\hline 40 & 1 & 0 & 0 & 0 & 0 & 1 & 12000 & 23 & 3 & 0 & 1 \\
\hline 41 & 1 & 0 & 0 & 0 & 0 & 8.5 & 100000 & 23 & 2 & 0 & 12 \\
\hline 42 & 0.9566 & -2.16 & -17916 & 0 & -2.43 & 9.84 & 112084 & 22 & 9.57 & 0.68 & 15.68 \\
\hline 43 & 0.5668 & 0 & 0 & -10.6 & -1.11 & 5.5 & 55000 & 25.445 & 4.89 & 3.821727 & 8.82173 \\
\hline 44 & 0.4791 & 0 & 0 & 0 & -7.24 & 3.7 & 30200 & 24 & 2.76 & 2.718168 & 5.21817 \\
\hline 45 & 1 & 0 & 0 & 0 & 0 & 12.5 & 150000 & 25 & 2.8 & 0 & 15 \\
\hline 46 & 1 & 0 & 0 & 0 & 0 & 1 & 13000 & 26 & 4 & 0 & 1.25 \\
\hline 47 & 0.5165 & 0 & -36977 & 0 & -7.97 & 3.7 & 43023.3 & 24 & 5.13 & 2.808333 & 5.80833 \\
\hline 48 & 1 & 0 & 0 & 0 & 0 & 1.25 & 8000 & 23 & 7.6 & 0 & 0.75 \\
\hline 49 & 0.7745 & -0.41 & 0 & 0 & 0 & 10.088 & 120000 & 25 & 6 & 3.494112 & 15.4941 \\
\hline 50 & 0.4954 & 0 & 0 & 0 & -6.19 & 3.3 & 30000 & 27 & 2.81 & 2.546611 & 5.04661 \\
\hline 51 & 0.5021 & 0 & -720 & -1.2 & -6.98 & 3.7 & 39280 & 28.8 & 3.53 & 2.975 & 5.975 \\
\hline 52 & 0.6407 & 0 & 0 & -6.05 & -3.53 & 2 & 15000 & 27.952 & 1.47 & 1.009612 & 2.80961 \\
\hline
\end{tabular}


Lanjutan Lampiran 1/Continue Appendix 1

\begin{tabular}{|c|c|c|c|c|c|c|c|c|c|c|c|}
\hline \multirow{2}{*}{ DMU } & \multirow{2}{*}{ Score } & \multicolumn{4}{|c|}{ Slack Movement } & \multicolumn{4}{|c|}{ Projection } & \multirow{2}{*}{$\begin{array}{l}\text { Prop. Mov. } \\
\text { Produksi }\end{array}$} & \multirow{2}{*}{$\begin{array}{c}\text { Projection } \\
\text { Produksi }\end{array}$} \\
\hline & & Land & Benih & TK & Jarak & Land & Benih & TK & Jarak & & \\
\hline 53 & 0.6607 & 0 & 0 & 0 & 0 & 2.5 & 27100 & 26 & 4 & 1.284132 & 3.78413 \\
\hline 54 & 0.8188 & 0 & 0 & -4.6 & 0 & 5 & 40000 & 25.399 & 3.4 & 1.272755 & 7.02276 \\
\hline 55 & 0.6704 & 0 & 0 & -5.04 & -2.57 & 9 & 50000 & 26.957 & 7.43 & 3.687082 & 11.1871 \\
\hline 56 & 0.5 & 0 & -2783 & 0 & -5.46 & 2 & 21216.7 & 28 & 3.04 & 1.5 & 3 \\
\hline 57 & 1 & 0 & 0 & 0 & 0 & 9 & 95200 & 1 & 7.3 & 0 & 8.75 \\
\hline 58 & 0.5556 & 0 & -4733 & -7.11 & -1.86 & 8 & 91166.7 & 26.889 & 7.94 & 6 & 13.5 \\
\hline 59 & 0.5161 & 0 & -4950 & -2 & -4 & 2.5 & 30050 & 26 & 5 & 1.875 & 3.875 \\
\hline 60 & 1 & 0 & 0 & 0 & 0 & 2.3 & 12000 & 25 & 1.25 & 0 & 3 \\
\hline 61 & 0.7407 & 0 & -19333 & -8.11 & -2.56 & 8 & 91166.7 & 26.889 & 7.94 & 3.5 & 13.5 \\
\hline 62 & 0.8936 & 0 & -4841 & 0 & 0 & 2.5 & 20459.2 & 26 & 2 & 0.381041 & 3.58104 \\
\hline 63 & 0.5674 & 0 & -798.3 & 0 & -4.95 & 2.3 & 26201.7 & 27 & 4.05 & 1.525 & 3.525 \\
\hline 64 & 0.6992 & -0.52 & 0 & -3.94 & -1.66 & 9.9843 & 112000 & 26.063 & 9.9 & 5.033618 & 16.7336 \\
\hline 65 & 0.6296 & 0 & -3833 & -2.11 & -3.06 & 8 & 91166.7 & 26.889 & 7.94 & 5 & 13.5 \\
\hline 66 & 0.5463 & 0 & 0 & -0.28 & -3.76 & 5.6 & 59300 & 26.718 & 5.24 & 4.153081 & 9.15308 \\
\hline 67 & 1 & 0 & 0 & 0 & 0 & 10 & 115300 & 26 & 10 & 0 & 17 \\
\hline 68 & 0.5966 & 0 & 0 & -2.57 & 0 & 6.4 & 65500 & 25.426 & 5.1 & 4.057189 & 10.0572 \\
\hline 69 & 0.5569 & 0 & 0 & -4.71 & -7.91 & 4 & 31500 & 25.29 & 3.09 & 2.586332 & 5.83633 \\
\hline 70 & 0.6788 & 0 & 0 & -10.9 & -5.35 & 7.5 & 63500 & 26.058 & 6.65 & 3.548573 & 11.0486 \\
\hline 71 & 0.6296 & 0 & -21633 & -8.11 & -5.26 & 8 & 91166.7 & 26.889 & 7.94 & 5 & 13.5 \\
\hline 72 & 0.9009 & 0 & 0 & -6.28 & 0 & 6 & 45900 & 25.717 & 4.5 & 0.825352 & 8.32535 \\
\hline 73 & 0.7931 & 0 & 0 & -1.35 & -0.6 & 3.5 & 31600 & 26.647 & 2.9 & 1.108793 & 5.35879 \\
\hline 74 & 0.7416 & -0.09 & 0 & -6.31 & 0 & 10.164 & 120000 & 25.688 & 7.5 & 4.180214 & 16.1802 \\
\hline 75 & 1 & 0 & 0 & 0 & 0 & 1.25 & 10000 & 25 & 4.5 & 0 & 1.5 \\
\hline 76 & 0.7407 & 0 & -20133 & -2 & -2.33 & 8 & 92566.7 & 26 & 8.67 & 3.5 & 13.5 \\
\hline 77 & 0.5455 & 0 & -9933 & 0 & -6.53 & 3 & 35066.7 & 24 & 4.67 & 2.083333 & 4.58333 \\
\hline 78 & 0.5786 & 0 & 0 & -1 & -0.21 & 9 & 95500 & 26.004 & 8.69 & 6.190263 & 14.6903 \\
\hline 79 & 0.5722 & 0 & 0 & -6.12 & -0.79 & 8.5 & 91400 & 25.884 & 8.19 & 5.981954 & 13.982 \\
\hline 80 & 0.6496 & 0 & 0 & -11.1 & 0 & 9.5 & 100000 & 25.909 & 8.05 & 5.25973 & 15.0097 \\
\hline
\end{tabular}

